07

\title{
Создание и электрические свойства гетеропереходов $p-\mathrm{Cu}_{2} \mathrm{ZnSnS}_{4} / n-\mathrm{Si}$
}

\author{
(C) А. Юсупов ${ }^{1}$, К. Адамбаев ${ }^{1}$, 3.3. Тураев $^{2}$, С.Р. Алиев ${ }^{3}$, \\ A. Кутлимратов ${ }^{4}$
}

${ }^{1}$ Ташкентский автомобильно-дорожный институт, Узбекистан

${ }^{2}$ Национальный университет Узбекистана им. М. Улугбека, Ташкент

${ }^{3}$ Андижанский государственный университет, Узбекистан

${ }^{4}$ Физико-технический институт АН РУз, Ташкент, Узбекистан

E-mail: ayus@mail.ru

Поступило в Редакцию 23 сентября 2016 г.

Впервые получены анизотипные гетеропереходы $p-\mathrm{Cu}_{2} \mathrm{ZnSnS}_{4} / n$-Si методом сульфиризации базовых металлических слоев, предварительно напыленных на подложку из поликристаллического кремния. Анализируются вольт-амперные характеристики и обсуждаются механизмы токопрохождения в созданных структурах. Показано, что для прямого смешения характерны туннельнорекомбинационные процессы и токи, ограниченные пространственным зарядом. При обратных смещениях в гетеропереходе преобладают токи, ограниченные пространственным зарядом.

DOI: 10.21883/PJTF.2017.02.44193.16474

В последнее время растет интерес к полупроводниковым гетеропереходам благодаря ряду их преимуществ по сравнению с гомопереходами. Гетеропереходы (ГП) широко используются в электронике и фотовольтаике $[1,2]$. При изготовлении солнечных элементов (СЭ) на основе ГП в качестве поглощающего слоя используются прямозонные полупроводники с большим коэффициентом оптического поглощения.

Полупроводниковое четверное соединение $\mathrm{Cu}_{2} \mathrm{ZnSnS}_{4}$ (CZTS) pacсматривается как перспективный материал для создания поглощающего слоя СЭ $[3,4]$. CZTS является прямозонным полупроводником с шириной запрещенной зоны порядка $1.5 \mathrm{eV}[1,2]$ и обладает большим коэффициентом поглощения ( 10 $\left.\mathrm{cm}^{-1}[3]\right)[3,4]$. Его компонентами являются широко распространенные в природе, дешевые и нетоксичные элементы. На основе соединения $\mathrm{Cu}_{2} \mathrm{ZnSnS}(\mathrm{Se})_{4}$ за последние несколько лет созданы СЭ с эффективностью от 5.4 до $12.6 \%$ [5,6]. Поэтому CZTS 
считается перспективным материалом для замены индий-галлиевого соединения в тонкопленочных СЭ.

CЭ на основе CZTS в качестве барьерного перехода, как правило, включает ГП $\mathrm{CdS} / \mathrm{Cu}_{2} \mathrm{ZnSnS}_{4}$ [5,6]. Однако с учетом современных экологических норм необходимо исключить из состава СЭ токсичный кадмий. Поэтому возникает необходимость поиска альтернативного варианта барьерного перехода СЭ на основе CZTS.

В настоящей работе исследуются создание и электрические свойства анизотипных ГП $p$ - $\mathrm{Cu}_{2} \mathrm{ZnSnS}_{4} / n$-Si на подложке из поликристаллического Si.

Формирование тонкого слоя CZTS на Si-подложке осуществлялось в два этапа. На первом этапе на подложке из поликристаллического $\mathrm{Si}$ методом вакуумного напыления образовывали базовые слои компонентов. Процесс проводился в вакууме $(3-5) \cdot 10^{-5} \mathrm{~mm} \mathrm{Hg}$. На втором этапе производилась сульфиризация базового слоя из неограниченного источника, в закрытом объеме. Процесс формирования пленки CZTS проводился путем термического отжига образцов с базовыми слоями при температурах $400-620^{\circ} \mathrm{C}$, время отжига выбиралось в интервале 15-90 min. После отжига образцы остывали до $200^{\circ} \mathrm{C}$ со скоростью $10-15^{\circ} \mathrm{C} / \mathrm{min}$, а затем температуру довели до комнатной, вытаскивая ампулы из печи.

Измерены электрические параметры полученных пленок. Bсе образцы, полученные без специального легирования, обладали дырочным типом проводимости. Это, по-видимому, связано с тем, что при формировании пленок CZTS образуются такие структурные дефекты, как вакансия атомов меди $-V_{\mathrm{Cu}}$ и замещения атомом меди узла цинка $\mathrm{Cu}_{\mathrm{Zn}}$ [7]. Поверхностное сопротивление пленок CZTS составляло в пределах 30-55 $\Omega / \mathrm{sq}$.

Измеряли стационарные вольт-амперные характеристики (BAX) созданных ГП $p$ - $\mathrm{Cu}_{2} \mathrm{ZnSnS}_{4} / n-\mathrm{Si}$ при комнатной температуре. Омические контакты к структурам получили нанесением эвтектического состава сплава индий-галлий. Прямые и обратные ветви ВАХ $I(V)$-гетероструктуры приведены на рисунке. Из рисунка, $a$ видно, что гетероструктура обладает четко выраженными диодными характеристиками. Причем пропускное направление во всех ГП наблюдается при подаче положительной полярности внешнего смещения на пленку CZTS, что согласуется с зонной моделью исследуемого ГП [8]. Коэффициенты выпрямления в лучших структурах при $|V|=1-2 \mathrm{~V}$ достигали до зна-

7* Письма в ЖТФ, 2017, том 43, вып. 2 


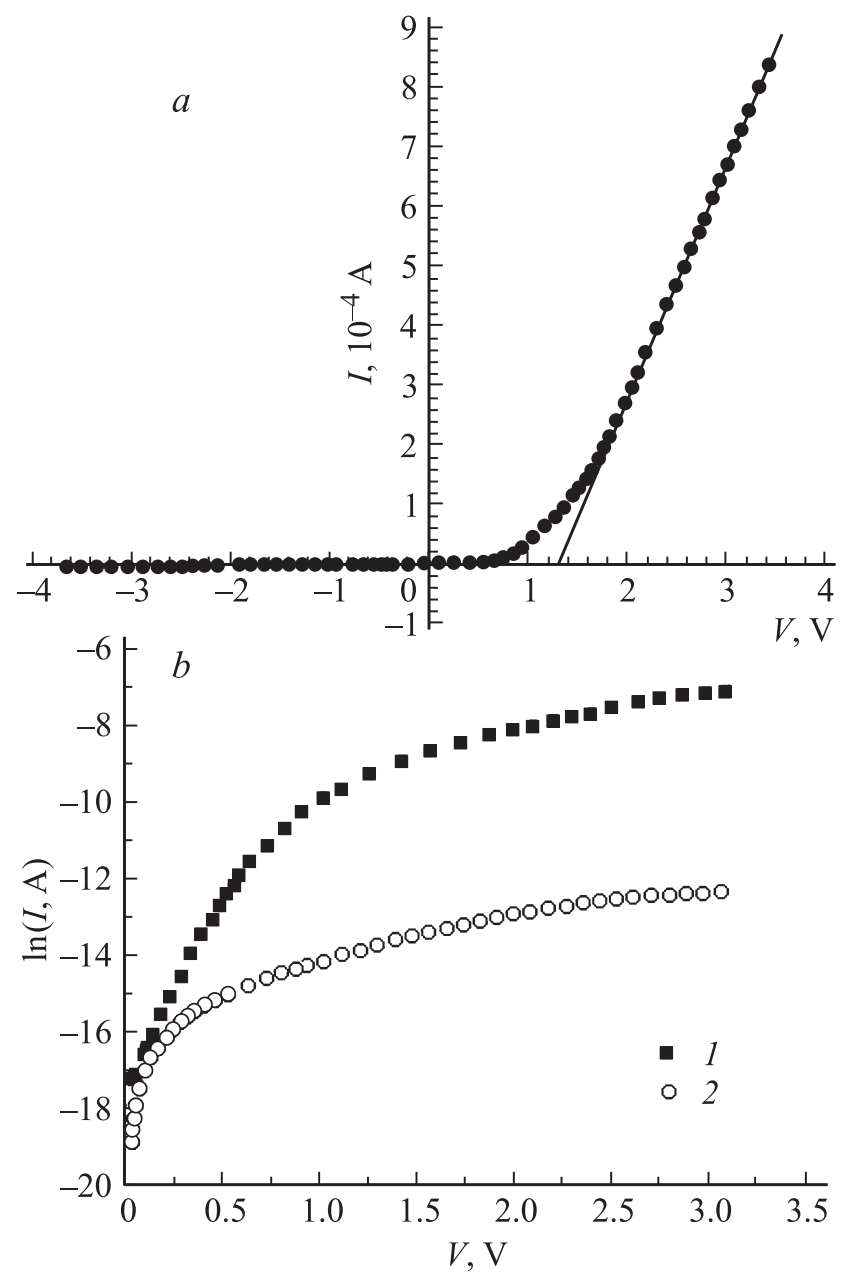

Стационарная ВАХ ГП $p$ - $\mathrm{Cu}_{2} \mathrm{ZnSnS}_{4} / n-\mathrm{Si}$ при $T=300 \mathrm{~K}$ в линейном $(a)$, полулогарифмическом $(b)$ и двойном логарифмическом масштабе $(c) .1-$ прямая ветвь, 2 - обратная ветвь.

чений $K=65-110$. Полученные сравнительно небольшие значения $K$, по-видимому, связаны с несовершенством переходной области ГП.

Письма в ЖТФ, 2017, том 43, вып. 2 


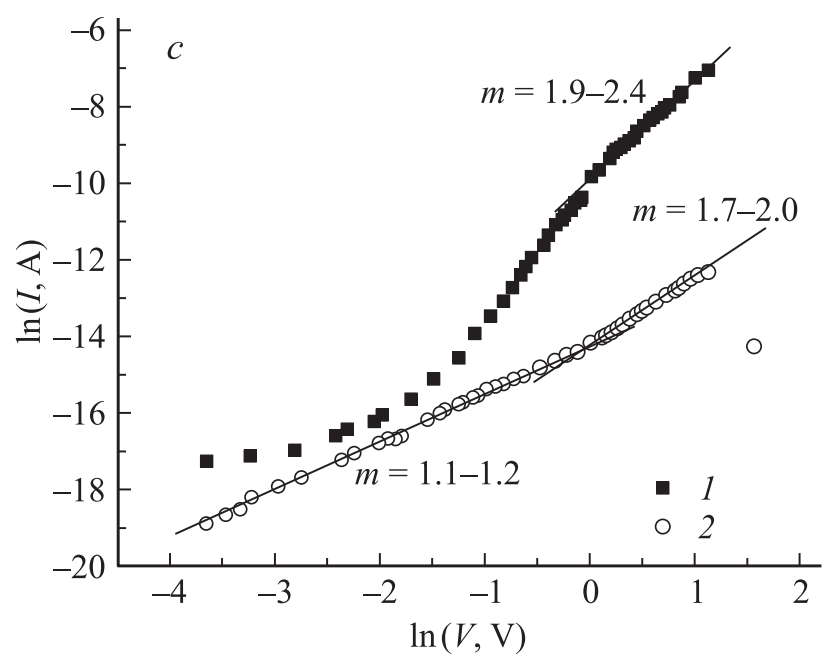

Рисунок (продолжение).

В области прямых напряжений $V<0.35 \mathrm{~V}$ (рисунок, $b$, кривая 1 ) прямой ток возрастает по следующему экспоненциальному закону:

$$
I=I_{s} \exp (e V / n k T),
$$

где $I_{s}$ - ток насыщения, $n-$ диодный показатель. Оценка их величин дала следующие результаты: $I_{s}=8 \cdot 10^{-7}-4 \cdot 10^{-8} \mathrm{~A}, n=3-4$ при $T=300 \mathrm{~K}$. Анализ этих величин показывает, что при небольших напряжениях в ГП более вероятным является туннельно-рекомбинационный механизм токопереноса.

Как видно из рисунка, $c$ (кривая 1), при напряжениях $0.35<V<2 \mathrm{~V}$ проявляется степенной механизм токопереноса, т.е. прямой ток подчиняется закону $I \sim V^{m}$. Значение показателя степени $m$ для различных структур составляло в пределах 1.9-2.4. Это указывает на преобладание токов, ограниченных пространственным зарядом в режиме подвижности [9]

$$
I=\left(8 \varepsilon \varepsilon_{0} \mu_{p} S / d^{3}\right) V^{2},
$$

где $\varepsilon-$ диэлектрическая проницаемость CZTS, $\varepsilon_{0}-$ диэлектрическая проницаемость вакуума, $S$ - площадь ГП, $d-$ толщина подложки.

Письма в ЖТФ, 2017, том 43, вып. 2 
Из рисунка, $a$ видно, что прямая ветвь $\mathrm{BAX} \mathrm{ГП} p-\mathrm{Cu}_{2} \mathrm{ZnSnS}_{4} / n$ - $\mathrm{Si}$ при напряжении $V>2 \mathrm{~V}$ подчиняется следующему линейному закону:

$$
V=V_{0}+I R_{B},
$$

где $V_{0}-$ напряжения отсечки, $R_{B}-$ сопротивление базы. Для ГП $p-\mathrm{Cu}_{2} \mathrm{ZnSnS}_{4} / n-\mathrm{Si}$ их величины составляли $1.4 \mathrm{~V}$ и $(3.5-6.6) \cdot 10^{3} \Omega$ соответственно. Изменение сопротивления базы в достаточно широких пределах, по-видимому, связано с изменениями условий кристаллизации пленок CZTS.

При обратном смещении ГП $p-\mathrm{Cu}_{2} \mathrm{ZnSnS}_{4} / n-\mathrm{Si}$ (см. рисунок, $b, c$, кривые 2) зависимость тока от напряжения также подчиняется степенному закону $I \sim V^{m}$ во всем интервале напряжений. Как видно из рисунка, $c$ (кривая 2), на обратных ветвях ВАХ можно условно выделить два участка. Для значений $|V|<1 \mathrm{~V}$ показатель степени составляет $m=1.1-1.2$. При увеличении напряжения $(|V|>1 \mathrm{~V})$ показатель степени увеличится до $m \approx 2$, в этой области $\mathrm{BAX}$ может быть описана с помощью квадратического закона (1).

Таким образом, впервые получены анизотипные ГП $p-\mathrm{Cu}_{2} \mathrm{ZnSnS}_{4} / n$-Si сульфиризацией базовых металлических слоев, предварительно напыленных на подложку из поликристаллического кремния. Из анализа $\mathrm{BAX}$ ГП $p-\mathrm{Cu}_{2} \mathrm{ZnSnS}_{4} / n$-Si установлены доминирующие механизмы токопереноса. При небольших прямых напряжениях $(V<0.35 \mathrm{~V})$ в ГП более вероятным является туннельнорекомбинационный процесс. В области напряжений $0.35<V<2 \mathrm{~V}$ преобладает ток, ограниченный пространственным зарядом в режиме подвижности (квадратичный закон). При напряжениях $V>2 \mathrm{~V}$ ВАХ изменяется по линейной зависимости. При обратном смещении в гетеропереходе преобладают токи, ограниченные пространственным зарядом.

\section{Список литературы}

[1] Sze S.M., Kwok K.N. Physics of semiconductor device. New Jersey, Wiley, 2007. $245 \mathrm{p}$.

[2] Фаренбрух А., Бьюб Р. Солнечные элементы: Теория и эксперимент. М.: Энергоатомиздат, 1987. 280 c. (Пер. с англ.: Fahrenbruch A.L., Bube R.H. Fundamentals of solar cells. Photovoltaic solar energy conversion. N.Y., 1983. 280 p.). 
[3] Hossain M.I. // Chalcogenide Lett. 2012. V. 9. N 6. P. 231-242.

[4] Persson C.J. // Appl. Phys. 2010. V. 107. P. 053710 (1-8).

[5] Katagiri H., Jimbo K., Jamada S. et al. // Appl. Phys. Express. 2008. P. 041201.

[6] Wang K., Gunawang O., Todorov T. et al. // Appl. Phys. Lett. 2010. V. 97. P. $144-150$.

[7] Гук М.С. Автореферат докторской диссертации. Кишинев: Ин-т прикладной физики АН Молдавии, 2014.

[8] Юсупов А., Адамбаев К., Тураев 3.3. // Гелиотехника. 2015. № 3. С. 52-55.

[9] Ламперт Г., Марк П. Инжекционные токи в твердых телах. М.: Мир, 1973. $414 \mathrm{c}$.

Письма в ЖТФ, 2017, том 43, вып. 2 